\title{
Determinants of gross domestic savings in Uganda: an autoregressive distributed lag (ARDL) approach to cointegration
}

\author{
Vivian Nagawa* ${ }^{*}$ Francis Wasswa and Edward Bbaale
}

\author{
*Correspondence: \\ vivienagawa@gmail.com \\ School of Economics, College \\ of Business and management \\ Sciences (COBAMS), Makerere \\ University, Kampala, Uganda
}

\begin{abstract}
In Uganda's development aspiration "VISION 2040", Uganda aspires to transform its society from a peasant to a modern and prosperous middle-income country by 2040, with per capita income of USD 9, 567. To attain the vision, savings as a percentage of GDP should be over $35 \%$. Notwithstanding such a high commitment, GDS as a percentage of GDP has remained below the desired target, standing at 16.5\% in 2017. This paper investigated the determinants of Gross Domestic Savings (GDS) in Uganda for the period 1980-2017. The theoretical framework is based on the life-cycle/permanentincome hypothesis. Augmented Dickey Fuller and Phillips-Perron tests were utilized to test for the stationarity of the time series variables in the model. To test for both the short-run and long-run relationships among GDS and the independent variables, the ARDL bounds testing approach was adopted. The observational results indicate that in the long run, Gross Domestic Product growth rate (GDPg), Foreign Domestic Investments (FDI) and Broad money (M2) have positive and statistically significant effects on GDS, while Current Account Balance (CAB) and Gross National Expenditure (GNE) have negative impacts on savings. Deposit Interest Rate (DIR) was observed to be a statistically unimportant determinant of GDS in Uganda. In the short run, CAB has a positive and statistically significant impact on GDS while GDPg and DIR have a negative and statistically significant impact on GDS. The paper recommends increasing net exports through implementation of the industrial and export strategy espoused in the national development plan 2. In addition, the government should ensure a predictable economic environment to act as an assurance to the foreign investors that their investments will yield profits.
\end{abstract}

Keywords: Autoregressive distributed lag (ARDL), Cointegration, Error-correction model, Gross domestic savings (GDS), Life-cycle/permanent-income theory

\section{Introduction}

Achieving sustainable economic growth is one of the fundamental targets of most economies. Over the years, domestic savings have been believed to be among the most influential determinants of economic growth by various economists (Nwachukwu 2012; Ndirangu and Muturi 2015). A nation's domestic savings play a very imperative role in attaining rapid and sustainable economic growth, that is higher savings provide funds

c) The Author(s) 2020. This article is licensed under a Creative Commons Attribution 4.0 International License, which permits use, sharing adaptation, distribution and reproduction in any medium or format, as long as you give appropriate credit to the original author(s) and the source, provide a link to the Creative Commons licence, and indicate if changes were made. The images or other third party material in this article are included in the article's Creative Commons licence, unless indicated otherwise in a credit line to the material. If material is not included in the article's Creative Commons licence and your intended use is not permitted by statutory regulation or exceeds the permitted use, you will need to obtain permission directly from the copyright holder. To view a copy of this licence, visit http://creativeco mmons.org/licenses/by/4.0/ 
needed for investment thereby prompting an expansion in production and employment eventually leading to economic growth and development.

The importance of savings in enhancing economic growth has been stressed by various growth theories. Most growth theories demonstrate existence of a positive relationship between savings and growth. For instance, the Harrod Domar model (1939) indicates that the growth rate of an economy has a positive relationship with that economy's savings ratio and a contrary relationship with its capital output ratio. This suggests that for an economy to grow, it ought to save a proportion of its Gross National Product (GNP) ${ }^{1}$ to boost capital formation. A standard neo-classical model of economic growth developed by Robert Solow in 1956 proposes that higher savings antecede economic growth, that is, a savings rate increase prompts an increment in investment and subsequently higher economic growth.

In addition, the endogenous growth theory as suggested by Romer (1986) asserts that higher rates of savings and investment are essential in an economy thanks to their strong and positive relationship with the GDP growth rate. They add that increments in savings in association with increases in the population size increase the long-run rate of growth of an economy.

Consistent with theoretical model outcomes, there is a wide accord within the empirical literature that low domestic savings are one among the foremost factors that impede the attainment of a high and sustainable economic growth among most of the African countries (Ndirangu and Muturi 2015; Nwachukwu 2012; Johnson 2015; Adewuyi et al. 2007; Epaphra 2014). East Asian economies like China, Indonesia, India, Malaysia, Singapore, and Thailand among others that have observed rapid economic growth for some years now are also characterized by high saving rates (Samantaraya and Patra 2014).

The limited levels of economic growth in various Sub-Saharan African countries can therefore be attributed to the low dimensions of domestic savings (Tesha 2013). The limited amounts of savings make them (sub-Saharan African countries) exceedingly dependent on foreign help in form of aid and loans. The high reliance on foreign assistance as a wellspring of investment finances makes a country susceptible to external shocks (Imoughele and Ismaila 2014). Therefore, to attenuate the vulnerability and defenselessness of an economy to external political and economic shocks, the nation ought to attempt to finance its investment needs using internally generated resources (Epaphra 2014).

The nexus between savings and economic growth is particularly vital for a developing nation like Uganda in whose development motivation as revered in the "VISION 2040", aspires to transform its economy from a typically peasant economy to a modern industrialized economy with per capita income of USD 9, 567 (GOU 2013) by the year 2040. To achieve the vision, Uganda must generate adequate resources to support her investment needs. There are numerous courses through which a nation can raise resources for her investment needs among which are but not constrained to, borrowing from abroad, capital inflows, taxation and domestic saving. However, borrowing from abroad 
is characterized by both short- and long-term antagonistic impacts to the economy as debt accumulation is considered a problem for macroeconomic stability.

Uganda has for the past years been borrowing to boost the quality of her infrastructure-capacity of electricity and transportation. These are done to establish a firm foundation for future growth (IMF 2016) and also to assist in the attainment of Vision 2040. Despite the fact that borrowing is for a decent purpose, the scaling up of public investment expenditure using borrowed funds has prompted a rise in Uganda's debt portfolio from six billion dollars in 2012 to ten billion dollars in 2017 (Background to the budget, 2017/2018). This debt burden is mortgaging both present and future generations to a forced obligation to pay back these loans with the debt per capita standing at $\$ 280$ in 2017 up from \$148 in 2000 (Uganda Debt Network 2017).

The increment in the debt has also expanded the risk of inability to service the loans which has made Uganda liable to defaulting (IMF 2017) just like the case 20 years back when Uganda's debt reached unsustainable levels. The end result was Uganda obtaining debt reliefs under the Highly Indebted Poor Country (HIPC) Initiative in 1998 and later on in 2000 under the Enhanced HIPC (Uganda Debt Network 2017). Whereas currently Uganda's debt level is sustainable and not expected to have an effect on growth, much exertion ought to be geared toward increasing domestic savings so as to avoid replay of history (Kasekende 2017). High debt levels (although still sustainable) combined with low tax-GDP ratio-tax revenue as a percentage of GDP stood at $14.05 \%$ in $2016 / 17$ (URA 2017)-leave no other option but domestic savings as the only feasible option to facilitate Uganda's investment needs and achieve the VISION 2040.

However, Uganda is one of the sub-Saharan Africa countries characterized by low saving rates. For the past 30 years, the highest GDS as a percentage of Gross domestic product (GDP) that Uganda has recorded was $18.89 \%$ in 1964. Four years later, GDS as a percentage of GDP declined to $14.41 \%$ but on account of increased private and official transfers from abroad bounced back to $17.23 \%$ in 1970 (Rujumba 1999). Nevertheless, later it declined to $5.7 \%$ in 1975.

By 1980 , GDS had plummeted to $-0.43 \%$ basically due to the civil war declared by then leader of the Republic of Uganda General Iddi Amin that resulted into the expulsion of Asians from Uganda hence affecting Uganda's macroeconomic environment. When the civil war ended in the year 1987, Uganda's GDS had further declined to $-0.08 \%$.

The macroeconomic stabilization endeavors by the government of Uganda that began in late 1980s including Economic Recovery Program (ERP) and Structural Adjustment Programs that started with currency reform, devaluations, liberalization of domestic prices, and eventually floating exchange rate regime by 1993 boosted GDS and by 1994 it had recuperated to $4.3 \%$. Due to increased private and official transfers from abroad, GDS as a percentage of GDP increased from 8.04\% in 2006 to 15.3\% in 2008. By 2017, it stood at $16.5 \%$ - which is fairly higher than that of other countries in the East African region like Rwanda (8.85\%) and Kenya (5.7\%) but lower than that of Tanzania (21.5\%) and the average of $17.2 \%$ for sub-Saharan Africa (Trading Economics 2017).

Several intercessions have been done by the government of Uganda to expand domestic savings among which are but not limited to; appropriate monetary policies aimed at guaranteeing positive deposit interest rates and policies to ensure an increase in domestic taxes through widening the tax base and increasing efficiency of the tax collection 
body. These strategy changes have however yielded minimal outcomes. In spite of the notable enhancement in Uganda's GDS from 1992 onwards, savings have remained quiet low below the targeted 35\% needed to support the country's development agenda (GOU 2017).

As previously mentioned, Uganda in her VISION 2040 aspires to transform the economy from a typically peasant to a competitive and prosperous middle-income economy by the year 2040. To fund investments adequate enough to realize the Vision, Uganda needs an adjustment in people's consumption, incomes and savings behavior as well as increase generation of government resources. The same VISION 2040 however acknowledges that one of the key impediments to Uganda's development is the low level of savings, which has denied the country low-cost investment capital.

It is a commitment that to achieve the vision, savings as a percentage of GDP ought to be $35 \%$ and above (GOU 2013). Notwithstanding such a high commitment, current trends display that GDS as a percentage of GDP has remained beneath the ideal target by 19 points, standing at 16.5\% in 2017 (World Bank 2018). Ugandan statistics have shown that during the years of improving savings, GDP growth was also increasing. For example, savings as a percentage of GDP increased from $14.35 \%$ in 2000 to $22.5 \%$ in 2008 and also GDPg increased from 3.14\% in 2000 to 8.7\% in 2008 (World Bank 2018). Low savings to GDP ratio coupled with immense external and domestic debt, low tax to GDP ratio plus high infrastructural developments may not goad the desired growth rates for the country to realize the Vision 2040. It is therefore important to study the determinants of GDS in Uganda since it is the least expensive wellspring of venture capital for the Uganda's investment needs.

\section{Literature review}

Consumption and savings are ordinarily studied together in savings and consumption theories. This is because a decision to consume automatically implies another decision of not saving what is expended (Makone 2016). There are four noteworthy theories that clarify the savings and consumption behavior of economic agents as discussed. Proposed by Keynes in 1936, the Absolute Income Hypothesis (AIH) builds up the link between income, consumption and savings. Keynes indicates that consumption and savings are increasing functions of the current disposable income-increase in current disposable income prompts an increase in both saving and consumption at the increasing and decreasing rates, respectively. The AIH theory infers that ceteris paribus, rich people save more than poor people.

In the Relative Income Hypothesis (RIH) which was created by James Duesenberry in 1949, consumption depends not on absolute income as Keynes proposed, but on relative income. Relative income refers to an individual's income in respect to the incomes of the reference group (group of individuals one feels is in competition with). Consumption by a household is determined by the income and consumption patterns of their neighbors. This implies that households with lower incomes in the reference groups spend more on consumption while households with higher incomes save more of their incomes (Duesenberry 1949).

In 1957, Milton Friedman developed the Permanent Income Hypothesis (PIH). To Milton, consumption depends neither on absolute income nor on relative income but 
on permanent/anticipated future income. This hypothesis splits income and consumption into transitory and permanent components. Permanent income is the average income determined by the expected income to be earned by an individual over an extensive period while Transitory/temporary income refers to the startling increment or decrease in income (Friedman 1957). Friedman's essential assumption is that permanent consumption relies on permanent income and consequently there is a fairly consistent average propensity to consume. However, changes in transitory/temporary income will prompt changes in savings, that is, the higher the transitory/temporary income, the higher the saving rate.

The Life Cycle Hypothesis (LCH) developed by Ando and Modigliani in 1963 suggests an individual's setup their saving and consumption patterns over their life-cycle. As the life-cycle begins, individuals have a relatively low-income stream in light of the fact that their productivity is low and consequently they are net borrowers. Amidst their life-cycle, people have a high-income stream; since their productivity is high, so they utilize the income they earned to reimburse prior aggregated debts and to save for retirement. In late years-years of retirement, the income decreases and people expend out of the previously accumulated savings (Ando and Modigliani 1963). Therefore, the LCH concludes that saving is positively related to income growth. This implies that a higher rate of income growth prompts an increment in income of active workers which in turn expands their permanent incomes on which both consumption and saving depend.

Empirically, Epaphra (2014) utilizing a Cointegration analysis studied the determinants of National savings in Tanzania for period of 1970 to 2010. The results of his study showed that Gross Domestic Product growth rate, disposable income, life-expectancy rates and Population growth rate positively affect Tanzanian national savings while Inflation adversely affects savings. Using cointegration and vector error-correction mechanism (VECM) and utilizing the 1991-2012 quarterly data, Ayetuoma and Muine (2014) analyzed the determinants of Namibia's Savings. Their results showed that the significant determinants of Namibia's savings were inflation rate, population growth rate and current income whereas variables like previous incomes, interest rates and broad money were found to be insignificant in determining savings behavior in Namibia.

Utilizing an ARDL bounds testing approach and error-correction model, Ayalew (2013) studied the determinants of Ethiopia's domestic savings. The analysis outcomes pointed out that the statistically significant determinants of domestic savings in Ethiopia were budget deficit ratio, income growth rate and inflation rate. Current account deficit, depositing interest rate and financial depth were found to be insignificant in explaining the changes in the domestic savings of Ethiopia. Further still, using an autoregressive distributed lag (ARDL), error-correction econometric modeling and time series data for the 1971-2011 period, Yohannes (2014) examined the determinants of Ethiopia's gross national saving. The results uncovered that in the long run, financial development and current account deficit are significant determinants of savings in Ethiopia whereas inflation, gross national disposable income, dependency ratio and budget deficit are factually irrelevant determinants of gross national saving in Ethiopia.

Arok et al. (2014) examined the determinants of gross domestic savings rate in Kenya using secondary annual data for the period 1971-2012. According to his results, in the long run, real per capita income significantly positively affects domestic savings rate 
in Kenya while public savings, interest rate on deposits and current account deficit adversely influence Kenya's domestic savings in the long run. Using both descriptive and ordinary least squares to estimate the household saving function, Reagan (2011) analyzed the factors that determine household savings in Uganda. The examination demonstrated that household income positively influences savings while net assets adversely affect savings. Demographic and social factors such as sex and literacy of head of household just as the location of the household do not significantly influence household saving behavior.

Utilizing the maximum likelihood framework, Kaberuka and Namubiru (2014) and Kariuki and Keino (2016) both empirically examined the effect of remittances on GDS in Uganda. Their results exhibited that remittances and foreign capital inflows have statistically significant negative impacts on Uganda's gross domestic savings. Kariuki and Keino (2016) furthermore unveiled that variables like interest rate on deposit, per capita GDP, rate of inflation and real effective exchange rate have positive impacts on Uganda's domestic savings.

From the literature reviewed above, there is no accord on the effect of the various factors on savings. Different investigation results have demonstrated that different factors affect savings distinctively given the country in which the investigations are carried out. This is on grounds that there are variations across the countries with regard to the institutional and structural factors that affect the economic factors that influence saving (Samantaraya and Patra 2014). The literature also shows that limited work has been carried out on the factors that determine Uganda's gross domestic savings. Some of the studies in Uganda like that of Reagan (2011) focused on determinants of household savings while others like Kaberuka and Namubiru (2014) looked at the effects of remittances on gross domestic savings. In their analysis, they did not include variables like Gross National Expenditure, Current Account Balance and Foreign Direct Investment which we believe may be important determinants of gross domestic savings in Uganda and hence shaping the basis for the present investigation.

\section{Theoretical framework}

The present study is based on Hall's random walk model of consumption also known as the life-cycle/permanent-income hypothesis. This was developed by Hall in 1978. It is the first theory to derive the rational expectation effects on consumption. Hall's hypothesis proposes that in case the permanent-income hypothesis is valid and that individuals have rational expectations, at that point any adjustments in consumption should be unpredictable-consumption should follow a random walk (Hall 1978).

$$
C_{t}=C_{t-1}+e_{t}
$$

Equation (3.1) shows that consumption follows a random walk. Random walk implies that Consumption in period $t$ depends on the previous period's consumption level plus an innovation term $e_{t}$.

Another assumption of Hall's random walk model is that individuals are rational and want to maximize the current value of their lifetime utility depending on a budget constraint. The study utilized an augmentation of the random walk hypothesis done by 
Romer (2012) in which he assumed a non-zero interest rate. In the analysis, Romer utilized an instantaneous utility function with constant relative risk aversion.

$$
U=\sum_{t=0}^{T} \frac{1}{(1+e)^{t}} \frac{C_{t}^{1-\theta}}{(1-\theta)},
$$

where $\theta=$ coefficient of constant relative risk aversion and $e=$ discount rate.

The budget constraint is equivalent to the current income in addition to the summation of the present value of expected lifetime income as shown in Eq. (3.3) below:

$$
\sum_{t=1}^{T} \frac{1}{(1+r)} C_{t} \leq A_{0}+\sum_{t=1}^{T} \frac{1}{(1+r)} Y_{t}
$$

\subsection{Optimization}

$$
L=\sum_{t=1}^{T} \frac{1}{(1+e)^{t}} \frac{C_{t}^{1-\theta}}{(1-\theta)}+\lambda\left(\sum_{t=1}^{T} \frac{C_{t}}{(1+r)^{t}} \leq A_{0}+\sum_{t=1}^{T} \frac{Y_{t}}{(1+r)^{t}}\right)
$$

First-order condition

$$
\begin{aligned}
& \frac{\partial L}{\partial C_{t}}=\frac{1}{(1+e)^{t} C_{t}^{\theta}}-\frac{\lambda}{(1+r)^{t}}=0 \\
& \frac{\partial L}{\partial C_{t+1}}=\frac{1}{(1+e)^{t+1} C_{t+1}^{\theta}}-\frac{\lambda}{(1+r)^{t+1}}=0
\end{aligned}
$$

Optimizing requires that marginal utility is the same over time, therefore from Eqs. (3.5) and (3.6) we get,

$$
\frac{1}{(1+e)^{t} C_{t}^{\theta}}-\frac{\lambda}{(1+r)^{t}}=\frac{1}{(1+e)^{t+1} C_{t+1}^{\theta}}-\frac{\lambda}{(1+r)^{t+1}}
$$

Implying that,

$$
C_{t}=\left(\frac{1+e}{1+r}\right)^{\frac{1}{\theta}} C_{t+1}
$$

From $S_{t}=Y_{t}-C_{t}$

$$
S_{t}=Y_{t}-\left(\frac{1+e}{1+r}\right)^{\frac{1}{\theta}} C_{t+1} .
$$

Taking expectations and putting into consideration that consumption follows a random walk we get, 


$$
S_{t}=Y_{t}-\left(\frac{1+e}{1+r}\right)^{\frac{1}{\theta}} C_{t} .
$$

Equation (3.10) above suggests that saving is positively identified with income and interest rate $(r)$ and negatively identified with consumption/absorption. The study in this way picks three variables from the theoretical model that is consumption/absorption, interest rate and income.

We augment the model in Eq. (3.10) above by including a number of variables recommended by other empirical work that might be helpful in explaining the gross domestic savings' behavior in Uganda. The included variables are assumed to have a direct or indirect impact on either or both income and consumption which have an effect on the savings. In addition, the new variables included in this model have not been studied previously in relation to savings in Uganda. These variables are Foreign Direct Investments, Current Account Balance and Broad Money. Therefore, the model selected is given as

$$
\mathrm{GDS}=\mathrm{F}(\mathrm{GDPg}, \mathrm{M} 2, \mathrm{DIR}, \mathrm{CAB}, \mathrm{FDI}, \mathrm{GNE}) .
$$

where GDS is Gross Domestic Saving, DIR is deposit interest rate, GDPg is Gross Domestic Product growth rate (\%), M2 is broad money, CAB is current account balance, GNE is Gross national expenditure (proxy for consumption/absorption) and FDI is foreign direct investment. GDS, M2, CAB, GNE and FDI are all measured as percentages of GDP.

The study adopts the Autoregressive Distributed Lag (ARDL) cointegration approach to establish both the short-run and long-run relationships among GDS and the explanatory variables shown in Eq. (3.11) above and to capture the speed of adjustment. Pesaran and Shin were the first to introduce the ARDL approach in 1998 (Pesaran and Shin 1999). Modification of the same was later done in 2001 by Pesaran, Shin and Smith (PSS 2001). The study adopted the ARDL due to its numerous advantages over the other two approaches to cointegration. For example, unlike the Johansen approach that needs all the variables in the model to be integrated of the same order (I(1)), the ARDL can absorb variables with different levels of integration-both I (0) and I (1) variables; likewise, it can be utilized to estimate both the long-run and short-run dynamics of the model simultaneously while avoiding the non-stationary time series data problems of endogeneity and autocorrelation. In addition, an ARDL model produces results which are unbiased and efficient even in studies associated with small samples. The estimable model is expressed as below 


$$
\begin{aligned}
\Delta \mathrm{GDS}_{t}= & a_{0}+a_{1} \mathrm{GDS}_{t-1}+a_{2} \mathrm{GDP}_{t-1}+a_{3} \mathrm{DIR}_{t-1} \\
& +a_{4} \mathrm{M}_{t-1}+a_{5} \mathrm{CAB}_{t-1}+a_{6} \mathrm{GNE}_{t-1} \\
& +a_{7} \mathrm{FDI}_{t-1}+\sum_{a=1}^{m} \beta_{a} \Delta \mathrm{GDS}_{t-a}+\sum_{b=0}^{n} \delta_{b} \Delta \mathrm{GDP}_{t-b} \\
& +\sum_{c=0}^{p} \sigma_{c} \Delta \mathrm{DIR}_{t-c}+\sum_{d=0}^{q} \mu_{d} \Delta \mathrm{M}_{t-d}+\sum_{e=0}^{r} \psi_{e} \Delta \mathrm{CAB}_{t-e} \\
& +\sum_{f=0}^{s} \theta_{f} \Delta \mathrm{GNE}_{t-f}+\sum_{g=0}^{v} \Omega_{g} \Delta \mathrm{FDI}_{t-g}+\phi \mathrm{ECT}_{t-1}+\varepsilon_{t}
\end{aligned}
$$

where $\Delta$ is the first difference operator, $\alpha_{0}$ is the drift component, $m, n, p, q, r, s$, and $v$ are the different variables' optimal lags obtained using the Bayesian information criterion (BIC) and $\phi$ is the speed of adjustment coefficient which shows the speed at which equilibrium is restored when disequilibrium occurs (note: $\phi$ should have a negative sign). The remaining set of variables is as previously characterized.

\section{Empirical methodology}

The ARDL approach utilized in this study does not require unit root tests preceding its estimation. In any case, to avoid the ARDL model crashing in presence of a variable(s) integrated of an order higher than 1, both the Dickey and Fuller (1981) and Phillips Perron (PP) (1988) tests were conducted on every variable included in the model to ascertain whether they are stationary or not and in case they are nonstationary, what their order of integration is.

Subsequent to establishing the order of integration of the different variables used in the model, the ARDL bounds testing approach to cointegration was carried out to check for the existence of a long-run relationship among the study variables. The null of no cointegration (Ho: $\alpha_{1}=\alpha_{2}=\alpha_{3}=\alpha_{4}=\alpha_{5}=\alpha_{6}=\alpha_{7}=0$ ) is tested against the alternative of Cointegration (Ha: $\alpha_{1} \neq \alpha_{2} \neq \alpha_{3} \neq \alpha_{4} \neq \alpha_{5} \neq \alpha_{6} \neq \alpha_{7} \neq 0$ ). To conclude whether cointegration exists or not, comparison between the computed $F$-statistic and the critical F-values provided by Pesaran et al. (2001) is done. Two sets of critical values - the lower bound critical value and upper bound critical value-were generated by Pesaran et al. (2001) for each level of significance. Pesaran et al. (2001) also developed different sets of critical values for the different variable categories of purely I (0), purely I (1) and for a combination of both I (0) and I (1) variables. The null of no cointegration is rejected when the computed $F$-statistic is above the upper critical value and we conclude that there is cointegration among variables in the model. In case the computed $F$-statistic is lower than the lower bound critical value, we fail to reject the null and conclude that there is no cointegration among variables in the model. If the computed $F$-statistic lies between the upper and lower limits, the test is uncertain and earlier knowledge about the order of integration is required so as to decide on the presence/absence of cointegration (Pesaran et al. (2001).

Another critical issue with the ARDL approach is selection of the appropriate lag length to use. ARDL model is estimated from a recursive search of the optimal number of lags through the use of either Schwarz Bayesian Information Criterion (SBIC) or Akaike Information Criterion (AIC). The ARDL model utilized in this study is 
Table 1 Correlation matrix. Source: Author's computation from World Development Indicators database for 2018

\begin{tabular}{lllllll}
\hline Variables & DIR & GDPg & M2 & CAB & GNE & FDI \\
\hline Deposit interest rate & 1 & & & & \\
GDPg & -0.0239 & 1 & & & \\
M2 & $(0.887)$ & & & & \\
& $-0.5166^{*}$ & 0.0732 & 1 & & \\
CAB & $(0.00090)$ & $(0.662)$ & & & \\
& 0.0142 & -0.170 & -0.278 & 1 & 1 \\
GNE & $(0.933)$ & $(0.308)$ & $(0.0911)$ & & \\
& 0.0772 & $0.5170^{*}$ & 0.118 & $-0.4443^{*}$ & 1 \\
FDI & $(0.645)$ & $(0.00090)$ & $(0.479)$ & $(0.00520)$ & \\
& $-0.5166^{*}$ & $0.4233^{*}$ & $0.7620^{*}$ & $-0.3567^{*}$ & $0.4132^{*}$ & 1 \\
& $(0.00090)$ & $(0.00810)$ & $(0.000)$ & $(0.0279)$ & $(0.0099)$ & \\
\hline
\end{tabular}

${ }^{* * *} p<0.01,{ }^{* *} p<0.05,{ }^{*} p<0.1$

selected by SBIC on grounds that as per Pesaran and Smith (1998) a model chosen by SBIC is a more parsimonious model which saves degrees of freedom especially in studies with small sample size like the current study. To test for the suitability of the model, diagnostic tests on heteroscedasticity, serial correlation, multicollinearity, parameter stability, normality and model specification were carried out.

\section{Data types and sources}

The study utilized secondary annual data for the 1980-2017 period. Data on the variable selected for the study were secured from the World Development Indicators database. The choice of the study period was due to availability of consistent data on the selected variables.

\section{Presentation of findings}

\subsection{Correlation matrix of variables}

The correlation matrix below demonstrates that the pair-wise correlations between dependent variables are not high-less than 0.8 . This suggests that multicollinearity which is the dependence between two dependent variables is not a significant problem in this model (Table 1).

\subsection{Unit root tests}

Table 2 presents the outcomes from both the Augmented Dickey Fuller (ADF) and Phillips-Perron (PP) unit root tests conducted on the variables in the model.

The null hypothesis of presence of unit root cannot be rejected for all the variables in the model except for Gross Domestic Product growth rate (GDPg) and Current Account Balance (CAB) which are stationary at $5 \%$ level of significance. The remaining variables become stationary after the first difference. Since the model comprises both I (0) and I (1) variables, ARDL bounds approach was adopted to test for cointegration among variables in the model. 
Table 2 ADF and PP unit root tests for stationarity: levels and first difference. Source: Author's computation from World Development Indicators database for 2018

\begin{tabular}{lll}
\hline Variables & Levels & FIRST difference \\
& T-Stat & T-Stat \\
\hline ADF-test & & \\
GDS & -1.448 & $-3.957^{* * *}$ \\
DIR & -2.114 & $-5.406^{* * *}$ \\
GDPg & $-4.597^{* * *}$ & - \\
M2 & -0.960 & $-5.717^{* * *}$ \\
CAB & $-3.071^{* *}$ & - \\
GNE & -2.482 & $-6.426^{* * *}$ \\
FDI & -1.598 & $-5.329^{* * *}$ \\
Critical values & $1 \%,-3.675$ & $1 \%,-3.689$ \\
& $5 \%,-2.969$ & $5 \%,-2.975$ \\
Phillips Peron test & $10 \%,-2.617$ & $10 \%,-2.619$ \\
GDS & & $-6.972^{* * *}$ \\
DIR & -1.293 & $-5.388^{* * *}$ \\
GDPg & -2.092 & - \\
M2 & $-7.081^{* * *}$ & $-5.754^{* * *}$ \\
CAB & -0.797 & - \\
GNE & $-3.242^{* *}$ & $-6.551^{* * *}$ \\
FDI & -2.497 & $-5.290^{* * *}$ \\
Critical values & -1.487 & $1 \%,-3.675$ \\
& $1 \%,-3.668$ & $5 \%,-2.969$ \\
& $5 \%,-2.966$ & $10 \%,-2.617$ \\
\hline
\end{tabular}

**Significant at 5\%

***Significant at $1 \%$

Table 3 Results of bounds test using F-statistic (U=upper, $L=$ lower). Source: Author's computation from World Development Indicators database for 2018

\begin{tabular}{|c|c|c|c|c|c|c|}
\hline \multirow[t]{3}{*}{ F-statistic } & \multicolumn{6}{|c|}{ Critical values } \\
\hline & \multicolumn{2}{|l|}{$10 \%$} & \multicolumn{2}{|l|}{$5 \%$} & \multicolumn{2}{|l|}{$1 \%$} \\
\hline & L-bound & U-bound & L-bound & U-bound & L-bound & U-bound \\
\hline 9.650 & 2.12 & 3.23 & 2.45 & 3.61 & 3.15 & 4.43 \\
\hline
\end{tabular}

The ARDL model selected by SBIC is ARDL $(1,1,1,0,3,0,0)$ with maximum lag of three, where variables GDS, DIR, GDPg are lagged once, CAB is lagged three times and the rest of the vairables are not lagged. 
Table 4 Results of diagnostic tests carried out. Source: Author's computation from World Development Indicators database for 2018

\begin{tabular}{|c|c|c|c|c|c|}
\hline Problem & Test carried out & Null hypothesis & Statistic & $\begin{array}{l}\text { Probability } \\
\text { value }\end{array}$ & Conclusion \\
\hline Serial correlation & $\begin{array}{l}\text { Breusch-Godfrey } \\
\text { LM Test (BG } \\
\text { test) }\end{array}$ & $\begin{array}{l}\text { No serial correla- } \\
\text { tion }\end{array}$ & $1.950($ Chi2(1)) & 0.1626 & $\begin{array}{l}\text { Fail to reject the } \\
\text { null hypoth- } \\
\text { esis }\end{array}$ \\
\hline $\begin{array}{l}\text { Heteroscedas- } \\
\text { ticity }\end{array}$ & $\begin{array}{l}\text { Breusch-Pagan/ } \\
\text { Cook-Weisberg } \\
\text { test }\end{array}$ & $\begin{array}{l}\text { Homoscedas- } \\
\text { ticity }\end{array}$ & $0.11($ Chi2(1)) & 0.7443 & $\begin{array}{l}\text { Fail to reject the } \\
\text { null hypoth- } \\
\text { esis }\end{array}$ \\
\hline $\begin{array}{l}\text { Model specifica- } \\
\text { tion }\end{array}$ & $\begin{array}{l}\text { Ramsey RESET } \\
\text { test }\end{array}$ & $\begin{array}{l}\text { Model has no } \\
\text { omitted vari- } \\
\text { ables }\end{array}$ & $0.71(F(3,15))$ & 0.5573 & $\begin{array}{l}\text { Fail to reject the } \\
\text { null hypoth- } \\
\text { esis }\end{array}$ \\
\hline Normality & Jarque-Bera test & $\begin{array}{l}\text { Residuals are } \\
\text { normally } \\
\text { distributed }\end{array}$ & $0.3048($ Chi2(2)) & 0.8586 & $\begin{array}{l}\text { Fail to reject the } \\
\text { null hypoth- } \\
\text { esis }\end{array}$ \\
\hline Multicollinearity & VIF & & 4.11 (mean VIF) & & $\begin{array}{l}\text { The model does } \\
\text { not suffer from } \\
\text { multicollin- } \\
\text { earity }\end{array}$ \\
\hline $\begin{array}{l}\text { Parameter stabil- } \\
\text { ity }\end{array}$ & $\begin{array}{l}\text { CUSUM6 and } \\
\text { CUSUM } \\
\text { squared }\end{array}$ & $\begin{array}{l}\text { Parameters are } \\
\text { stable }\end{array}$ & & & $\begin{array}{l}\text { The null hypoth- } \\
\text { esis cannot } \\
\text { be rejected at } \\
\text { the } 5 \% \text { critical } \\
\text { bound (as can } \\
\text { be seen in } \\
\text { Appendix A) }\end{array}$ \\
\hline
\end{tabular}

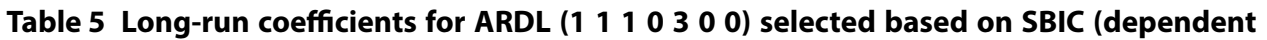
variable is GDS). Source: Author's computation from World Development Indicators database for 2018

\begin{tabular}{|c|c|c|c|c|c|c|}
\hline \multicolumn{5}{|c|}{ Variables } & & Coefficient \\
\hline \multirow{2}{*}{\multicolumn{6}{|c|}{ Deposit interest rate (DIR) }} & 0.133 \\
\hline & & & & & & $(0.078)$ \\
\hline \multirow{2}{*}{\multicolumn{6}{|c|}{ Gross domestic product growth rate (GDPg) }} & $0.686^{* * *}$ \\
\hline & & & & & & $(0.228)$ \\
\hline \multirow{2}{*}{\multicolumn{6}{|c|}{ Broad money (M2) }} & $0.500^{* * *}$ \\
\hline & & & & & & $(0.144)$ \\
\hline \multirow{2}{*}{\multicolumn{6}{|c|}{ Current account balance (CAB) }} & $-0.817^{* * *}$ \\
\hline & & & & & & $(0.201)$ \\
\hline \multirow{2}{*}{\multicolumn{6}{|c|}{ Gross national expenditure (GNE) }} & $-0.810^{* * *}$ \\
\hline & & & & & & $(0.158)$ \\
\hline \multirow{2}{*}{\multicolumn{5}{|c|}{ Foreign direct investment (FDI) }} & & $0.815^{*}$ \\
\hline & & & & & & $(0.413)$ \\
\hline \multicolumn{7}{|c|}{ Standard errors in parentheses } \\
\hline \multicolumn{7}{|c|}{${ }^{* * *} p<0.01,{ }^{* *} p<0.05,{ }^{*} p<0.1$} \\
\hline GDS & DIR & GDPg & M2 & $\mathrm{CAB}$ & GNE & FDI \\
\hline 1 & 1 & 1 & 0 & 3 & 0 & 0 \\
\hline
\end{tabular}

Source: Author's computation from World Development Indicators database for 2018 
Table 6 Short-run coefficients for ARDL ( $\left.\begin{array}{llllll}1 & 1 & 1 & 0 & 3 & 0\end{array}\right)$. Source: Author's computation from World Development Indicators database for 2018

\begin{tabular}{ll}
\hline Variable & Coefficient \\
\hline D.DIR & $-0.208^{* *}$ \\
D.GDPg & $(0.086)$ \\
& $-0.552^{* * *}$ \\
D.CAB & $(0.171)$ \\
& $0.784^{* * *}$ \\
LD.CAB & $(0.230)$ \\
& $0.865^{* * *}$ \\
L2D.CAB & $(0.193)$ \\
& $0.412^{* * *}$ \\
Constant & $(0.138)$ \\
ECM t-1 & $77.015^{* * *}$ \\
Observations & $(15.832)$ \\
$F(12,22)$ & $-0.820^{* * *}$ \\
Prob $>F$ & $(0.132)$ \\
$R$-squared & 35 \\
Adj $R$-squared & 7.54 \\
\hline Starders & 0.000 \\
\hline
\end{tabular}

Standard errors in parentheses

${ }^{* * *} p<0.01,{ }^{* *} p<0.05,{ }^{*} p<0.1$

\subsection{Testing for cointegration}

Table 3 presents the test results for the bounds test.

Basing on the bounds test results in Table 3, we reject the null hypothesis of no cointegration among variables since the $F$-statistic is greater than the upper bound critical values at all levels of significance. We therefore conclude the presence of cointegration.

Prior to presenting the main estimation results, it is important to present the diagnostic test results to ascertain the robustness and statistical appropriateness of the model. The diagnostic test results are presented in Table 4.

All the conclusions in Table 4 with an exception of the one for VIF and CUSUM6 and CUSUM squared are based on the fact that the probability values for all the tests carried out are greater than 0.05 significance level.

\subsection{Goodness of fit $\left(R^{2}\right)$}

The model was found to be a good fit for the data. This conclusion is based on the high $R$-squared of 0.8752 . This suggests that $87.5 \%$ of the alterations in the explained variable (GDS) are accounted for by the independent variables in the model.

\subsection{F-statistic and the overall performance of the model}

The joint statistical performance of the model shown by the $F$-statistic is 7.54 with a probability value of 0.000 which suggests that in the long run, the explanatory variables jointly determine GDS in Uganda. 


\subsection{Presentation of regression results}

The proceeding Tables 5 and 6 shows the long-run and short-run coefficients for ARDL

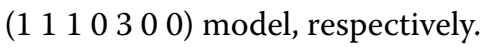

\section{Discussion of findings}

The outcomes from the model estimation show that in the long run, all variables except Deposit Interest Rate have statistically significant impacts on GDS. GDPg has a positive and statistically significant (at $5 \%$ level of significance) impact on GDS. In other words ceteris peribus, a percentage change in GDP growth rate prompts 0.69 percentage change in GDS in a similar direction. This result is in line with the theories of consumption and savings theories such as the life-cycle hypothesis which assumes a positive relationship between income and savings and with the Random walk hypothesis predicts that higher GDP growth rate countries are envisaged to have savings higher than that of low-GDP growth rate countries. The outcome is also consistent with empirical works of Ahmed (2011), Kidane (2010) and Ayalew (2013) who likewise find a positive and statistically significant link between GDP growth rate and domestic savings in their studies.

Broad money (M2) has a statistically significant (at 5\% level of significance) positive impact on GDS in the long run. Keeping other factors constant, a percentage change in M2 will prompt a change in GDS by approximately $0.50 \%$ in the same direction. The outcome demonstrates that the availability and accessibility of a number of financial assets like central bank securities and or other time deposits with higher interest rates coupled with the improvement in the proximity, and hence accessibility to banking facilities, motivate individuals to save. This outcome is consistent with Ahmad and Mahmood (2013) who found statistically significant positive relationship between savings and broad money. However, it contradicts the findings of Ogbokor and Samahiya (2014) who found that M2 had a negative effect on GDS in Namibia.

As expected, Gross National Expenditure has a statistically significant (at 5\% level of significance) adverse impact on Gross Domestic Savings in Uganda in the long run. The coefficient of -0.81 suggests that keeping other factors constant, a percentage change in GNE prompts an opposite change in GDS of approximately $0.81 \%$. This is consistent with the Keynesian model of saving and consumption which postulates that savings are a decreasing function of consumption/absorption.

In addition, Current Account Balance has a statistically significant (at 5\% significance level) negative impact on gross domestic savings. The -0.81 coefficient suggests that a percentage change in $C A B$ leads to a negative change in GDS of approximately $0.81 \%$. The negative sign of the impact of CAB on GDS can be attributed to high indebtness of the country. Savings in Uganda are less than Uganda's investment needs and hence to cover the saving-investment gap, Uganda finds herself borrowing. It should be noted that in the long run, almost all the debts received by Uganda have matured and therefore need servicing. Revenues got from exports are therefore used in the servicing of loans and hence leading to reduction in savings (Pettinger 2017). In addition, a reduction in current account balance (deficit) implies an expansion in foreign savings and decrease in domestic savings because foreign 
savings are a substitute to domestic savings (Narayan et al. 2017. This result is consistent with the results of Touny (2008), Narayan et al. (2017), (Özcan 2003) and Arok et al.(2014) who also found a negative relationship between current account balance and savings.

FDI has a statistically significant (at $10 \%$ level of significance) positive impact on GDS. The coefficient of 0.81 suggests that a percentage increment in FDI prompts an increase in GDS by approximately $0.81 \%$. And a percentage decrease in FDI leads to a 0.81 percentage decrease in GDS. This result infers that an increase in FDI increases investments in Uganda which increases the number of jobs available in the country which in turn leads to increased employment, increased income and eventually increased savings. The outcome is consistent with the findings of Azam and Shakeel (2012) and by Chani et al. (2010) who also found a statistically significant positive impact of FDI on savings.

DIR is found to be a statistically unimportant determinant of GDS in Uganda. This may be because of the low levels of financial sector development in Uganda. The result is consistent with that of Kidane (2010) and Ayalew (2013) who also find deposit interest rate insignificant in determining savings in their respective studies.

In the short run, Current Account Balance has a positive and statistically significant impact on the GDS. On the other hand, GDP growth rate and deposit interest rate (DIR) have statistically significant (at $5 \%$ level of significance) adverse impacts on savings. That is, a percentage increase in GDPg and DIR leads to a reduction in GDS by 0.55 and $0.21 \%$, respectively. The negative effect from GDPg may be due to the income effect where by an increase in income leads to an increase in consumption and consequently leading to low savings especially by low-income earners. The negative effect of DIR may be due to the low levels of consumer confidence in the economy. The error-correction term coefficient is found to be significant at all levels of significance with the right sign and magnitude. The speed of adjustment $\left(\mathrm{ECM}_{t-1}\right)$ is -0.82 . This suggests that approximately $82 \%$ of the adjustment toward long-run equilibrium takes place per year. It also shows that if disequilibrium happens, it will take more than 1 year for GDS to adjust itself toward its long-run equilibrium.

\section{Conclusion}

The study revealed positive relationships between GDS, GDPg, M2 and FDI. GDPg and M2 were found to be significant explanatory variables at 5\% significance level while FDI was found to be significant at $10 \%$ significance level. This suggests that a change in GDP growth rate, M2 and FDI leads to a change in GDS in the same direction. The study also showed that $\mathrm{CAB}$ and GNE have statistically significant (at $5 \%$ level of significance) adverse impacts on GDS. This suggests that an increase or decrease in GNE or $\mathrm{CAB}$ leads to a decrease or increase in GDS, respectively. Deposit interest rate, on the other hand, was found to be a statistically significant determinant of GDS but only in the short run. In the long run, it was found to be statistically insignificant in determining the changes in GDS. 


\title{
9 Policy implications and recommendations
}

Based on the empirical results from the study, the study recommends that policy makers in Uganda should put more emphasis on Gross Domestic Product growth rate, Current Account Balance and Foreign Direct Investment. The policy implications and recommendations suggested by the study include the following: A policy measure to reduce the adverse effects of CAB (deficit) on GDS should focus on expanding exports through implementing the Industrial and export strategy espoused in the NDPII and reducing over importation especially of goods that can be produced in Uganda through import substitution. Such policies will reduce imports and improve exports' earnings which will in turn increase savings. There is also need to formulate policies which will trigger GDP growth rate. This can be done by mainly focusing on the sectors that are the main drivers of the economy like the service sector, agricultural sector among others. Particularly, the government can give incentives to investors in both the service and the agricultural sectors so as to attract bigger investments. A stable and predictable economic environment should also be availed so as to act an assurance to investors that their investments will yield the expected returns. A stable economic environment consists of corruptionfree bodies, controlled inflation and favorable interest rates. These will help attract more FDIs into Uganda and hence increase GDS.

\begin{abstract}
Abbreviations
ADF: Augmented Dickey Fuller; AIC: Akaike Information Criterion; ARDL: Autoregressive distributed lag model; BG: Breusch Godfrey; BP: Breusch-Pagan; CAB: Current account balance; DIR: Deposit interest rate; FDI: Foreign domestic investment; GDP: Gross domestic product; GDPg: Gross domestic product growth rate; GDS: Gross domestic savings; GNE: Gross national expenditure; GNP: Gross national product; GOU: Government of Uganda; HIPC: Highly indebted poor country; M2: Broad money; PP: Phillips-Perron; RESET: Regression equation specification error test; SBIC: Schwarz Bayesian Information Criterion; ECM: Vector error-correction mechanism; WDI: World Bank Development Indicators.
\end{abstract}

\section{Acknowledgements}

First, I thank my family and friends for all the help and support rendered to me throughout the entire process of writing this manuscript. I thank the staff of the School of Economics and the entire staff of the College of Business and Management Sciences (CoBAMS) for their help, support, and comments they rendered me during the process of developing this manuscript.

\section{Authors' contributions}

VN is the main author of the manuscript. She initiated the research idea, developed the research proposal, acquired data from World development indicators and other sources, analyzed the data and developed the manuscript. FW and EB are co-authors of this manuscript. They approved the research proposal, supported the development of the research paper, undertook quality assurance and supported the empirical data analysis and generation of policy implications. All authors read and approved the final manuscript.

\section{Funding}

Not available.

\section{Availability of data and materials}

The study covered the period 1980-2017 and it used secondary annual data. All the data used in this study were sourced from the World Development Indicators (WDI) CD-ROM accessed at (https://data.worldbank.org/country/uganda?view).

The data are available on request from the corresponding author.

\section{Competing interests}

All the three authors of this manuscript declare that they have no competing interest in this publication. 


\section{Appendix: CUSUM and CUSUMsq control charts}
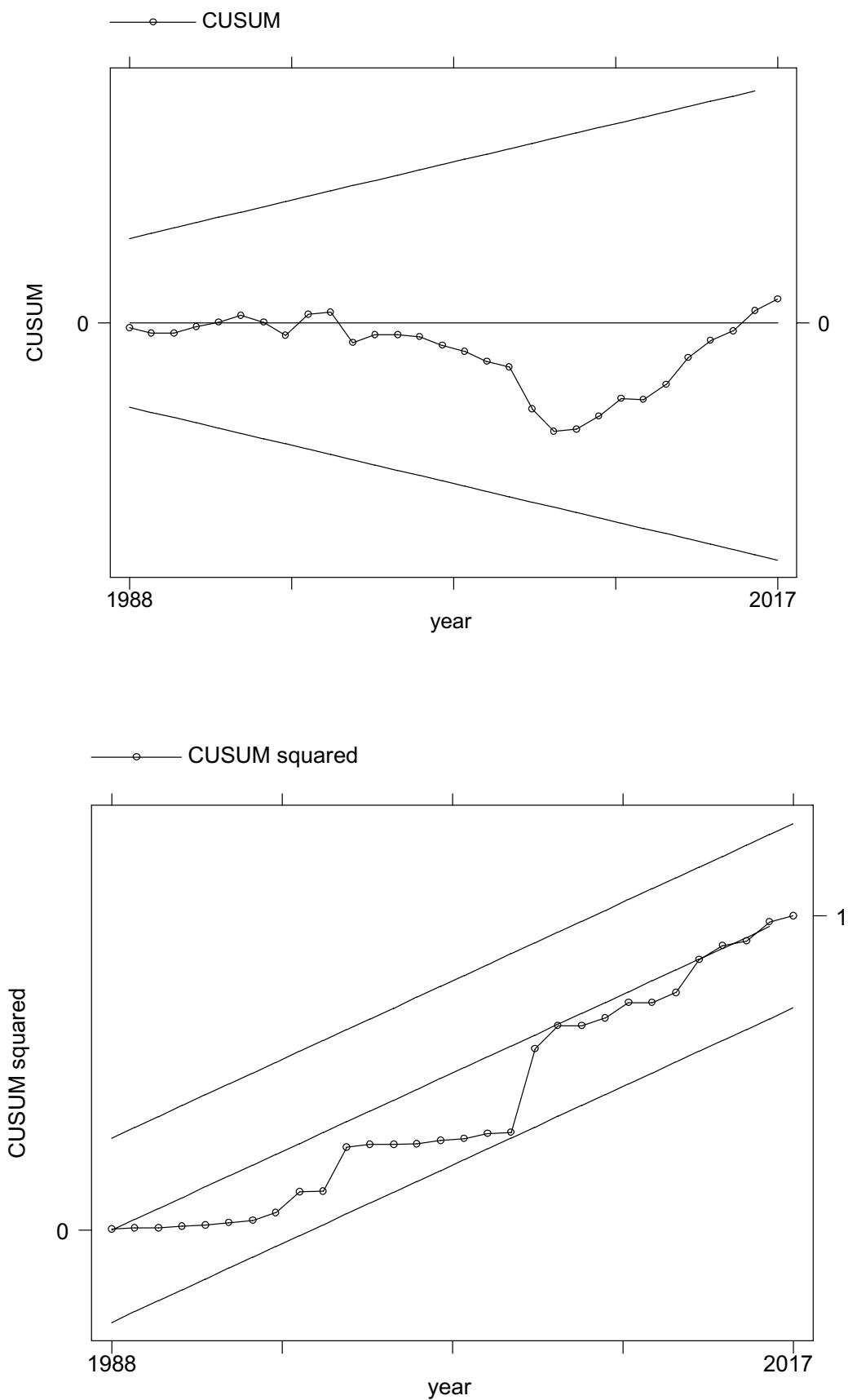

Received: 11 April 2019 Revised: 1 January 2020 Accepted: 11 April 2020

Published online: 12 May 2020

References

Adewuyi A, Bankole A, Arawomo D (2007) What determines saving in the economic community of West African State (ECOWAS)? J Monet Econ Integr 10(2):71-99 
Ahmad K, Mahmood H (2013) Macroeconomic determinants of national savings revisited: a small open economy of Pakistan. World Appl Sci J 21(1):49-57

Ahmed SMM (2011) Determinants of savings: empirical evidence from African countries, 1990-1999. The Academy of Islamic Figh, Sudan

Ando A, Modigliani F (1963) The "life cycle" hypothesis of saving: aggregate implications and tests. Am Econ Rev 53(1):55-84

Arok BA, Mwega FM, Gor DSO (2014) Determinants of gross domestic savings in Kenya (Doctoral dissertation, Thesis for Master of Arts in Economics of the University of Nairobi)

Ayalew HA (2013) Determinants of domestic saving in Ethiopia: an autoregressive distributed lag (ARDL) bounds testing approach. J Econ Int Financ 5(6):248-257

Ayetuoma OC, Muine SO (2014) A time series analysis of the determinants of savings in Namibia

Azam M, Shakeel K (2012) Impact of foreign capital inflows on household saving in Pakistan. Eur J Sci Res 68(3):345-351

Chani D, Irfan M, Salahuddin M, Shahbaz MQ (2010) A note on causal relationship between FDI and savings in Bangladesh. Theor Appl Econ 17(11):53-62

Dickey DA, Fuller WA (1981) Likelihood ratio statistics for autoregressive time series with a unit root. Econometrica 49:1057-1072

Duesenberry J (1949) Income, savings and the theory of consumer behavior. Harvard University Press, London

Epaphra M (2014) Empirical investigation of the determinants of Tanzania's national savings. J Econ Dev Stud 2(4):223-241

Friedman M (1957) A theory of the consumption function. Nat. Bur. Econ. Res, New York

Government of Uganda (GOU) (2013) Uganda vision 2040. http://www.npa.go.ug/uganda-vision-2040/

Government of Uganda (2017) Background to the budget. https://www.finance.go.ug/budget/background-budget-fisca I-year-201718-industrialization-job-creation-and-shared-prosperity

Hall R (1978) Stochastic implications of the life cycle-permanent income hypothesis: theory and evidence. J Polit Econ 91:249-265

Harrod RF (1939) An essay in dynamic theory. Econ J 49(193):14-33

IMF (2016) Uganda seventh review under the policy support instrument - debt sustainability analysis. https://www.imf. org/external/pubs/ft/dsa/pdf/2017/dsacr1707.pdf

IMF (2017) Uganda selected issues. IMF Country Report No. 17/207. https://www.elibrary.imf.org/doc/IMF002/24441 -9781484309360/24441-9781484309360/Other_formats/Source_PDF/24441-9781484309513.pdf

Imoughele LE, Ismaila M (2014) An econometric analysis of the determinants of private domestic savings in Nigeria (1981-2012). Int J Humanit Soc Sci 4(5):12-21

Johnson AO (2015) An investigation of the determinants of savings and investment in Nigeria. Issues Econ Bus 1(2):1

Kaberuka W, Namubiru R (2014) The effect of remittances on gross domestic savings in Uganda (1999-2011). Int J Bus Manag Adm 3(2):29-39

Kasekende L (2017) Annual dinner for the Uganda Bankers' Association (UBA). https://www.bou.or.ug/bou/bouwebsite/ bouwebsitecontent/MediaCenter/DeputyGovernorSection/speeches/DeputyGovernorsSpeeches/2017/Nov/Remar ksby-Deputy-Governor-Dr-Louis-Kasekende-at-the-UBA-end-of-Year-Dinner-Nov-24-2017.pdf

Kariuki N, Keino A (2016) Effect of remittances on gross domestic savings in Uganda. Int Scholars J

Kidane BM (2010) Determinants of gross domestic saving in Ethiopia: a time series analysis (1971-2009). In: 4th annual multidisciplinary research conference of alpha, University College, pp 23-24

Mokone M (2016) Determinants of savings in Lesotho. In: Presented at AERC JFE seminar series, 14th July 2016

Narayan PK, Narayan S, Phan DHB, Thuraisamy KS, Tran VT (2017) Credit quality implied momentum profits for Islamic stocks. Pac-Basin Financ J 42:11-23

Ndirangu E, Muturi W (2015) Determinants of gross domestic savings in Kenya (1970-2013). Int J Econ Commer Manag 3(7):157-178

Nwachukwu T (2012) Determinants of private saving in Nigeria

Ogbokor CA, Samahiya OM (2014) A time series analysis of determinants of savings in Namibia

Özcan MG (2003) Determinants of private savings behaviour in Turkey. Appl Econ 35:1405-1416

Pesaran MH Shin Y (1999) An autoregressive distributed lag modelling approach to cointegration analysis. Cambridge University Press, pp 371-413. https://doi.org/10.1017/CCOL521633230.011

Pesaran MH, Shin Y, Smith RJ (2001) Bounds testing approaches to the analysis of level relationship. J Appl Econ 16:289-326

Pettinger T (2017) Economics help

Phillips PCB, Perron P (1988) Testing for a unit root in time series regression. Biometrika 75(2):335-346

Reagan NR (2011) Determinants of household savings in Uganda. http://erepository.uonbi.ac.ke/bitstream/handle/11295 /3293/NAMANYA\%20RONALD\%20REAGAN\%20M.A._ECON_2011.pdf? sequence=1

Romer PM (1986) Increasing returns and long-run growth. J Polit Econ 94(5):1002-1037

Romer D (2012) Dynamic stochastic general equilibrium models of fluctuations. In: Advanced macroeconomics, 4th ed. McGraw-Hilllrwin, New York, pp 312-364

Rujumba GW (1999) Uganda. http://www.ic.keio.ac.jp/en/download/jjwbgsp/1999/1999_5Uganda.pdf

Samantaraya A, Patra SK (2014) Determinants of household savings in India: an empirical analysis using ARDL approach. Econ Res Int. https://doi.org/10.1155/2014/454675

Tesha DM (2013) Determinants of private saving in Tanzania. University of Nairobi, Nairobi

Touny MA (2008) Determinants of domestic saving performance in Egypt: an empirical study. J Commer Stud Res 1:1-23

Trading Economics (2017) Uganda -Gross Domestic Savings (\% of GDP). https://tradingeconomics.com/uganda/gross -domestic-savings-percent-of-gdpwb-data.html

Uganda Debt Network (2017) The trend of Uganda debt. https://udn.or.ug/resources/debt-unit-publications/214-thetrend-of-ugandadebt/file.htmlhttps://udn.or.ug/resources/debt-unit-publications/214-the-trend-of-ugandadebt/ file.html 
Uganda Revenue Authority (2017) Annual report 2016/17. https:/www.ura.go.ug/Resources/webuploads/GNRART/ Annual\%20Report\%202016-17.pdf

World Bank (2018) Gross domestic savings (\% of GDP) Uganda data. https://data.worldbank.org/indicator/NY.GDS.TOTL. ZS?locations=UG

Yohannes $G$ (2014) An empirical time series analysis on the determinants of gross national saving in Ethiopia: ARDL approach to co-integration (Doctoral dissertation, MSc Thesis. Addis Ababa University)

\section{Publisher's Note}

Springer Nature remains neutral with regard to jurisdictional claims in published maps and institutional affiliations.

Submit your manuscript to a SpringerOpen ${ }^{\circ}$ journal and benefit from:

- Convenient online submission

- Rigorous peer review

- Open access: articles freely available online

- High visibility within the field

- Retaining the copyright to your article

Submit your next manuscript at $\boldsymbol{\nabla}$ springeropen.com 